University of Denver

Digital Commons @ DU

Religious Studies: Faculty Scholarship

Religious Studies

2-2016

\title{
Who Heard What When: Learning from Radio Broadcasting Hours and Programs in Jerusalem
}

Andrea L. Stanton

University of Denver, andrea.stanton@du.edu

Follow this and additional works at: https://digitalcommons.du.edu/religious_studies_faculty

Part of the Islamic World and Near East History Commons

\section{Recommended Citation}

Stanton, A. L. (2016). Who heard what when: Learning from radio broadcasting hours and programs in Jerusalem. International Journal of Middle East Studies, 48(1), 141-145. https://doi.org/10.1017/ S0020743815001555

\section{(c) (i)}

This work is licensed under a Creative Commons Attribution 4.0 License.

This Article is brought to you for free and open access by the Religious Studies at Digital Commons @ DU. It has been accepted for inclusion in Religious Studies: Faculty Scholarship by an authorized administrator of Digital Commons@DU. For more information, please contact jennifer.cox@du.edu,dig-commons@du.edu. 


\section{Who Heard What When: Learning from Radio Broadcasting Hours and Programs in Jerusalem}

\section{Comments}

This article was originally published by Cambridge University Press in the International Journal of Middle

East Studies. The published version may be found at https://doi.org/10.1017/S0020743815001555.

\section{Publication Statement}

Copyright held by the author or publisher. User is responsible for all copyright compliance. 
This article was originally published by Cambridge University Press in the International Journal of Middle East Studies. The published version may be found at https://doi.org/10.1017/S0020743815001555.

Who Heard What When: Learning from Radio Broadcasting Hours and Programs in Jerusalem

Andrea Stanton

Andrea Stanton is an assistant professor of Islamic Studies in the Department of Religious

Studies at the University of Denver in Denver, Colorado. Her email address is andrea.stanton@du.edu. 
Incorporating descriptions and analyses of sound into Middle Eastern history offers a wealth of opportunity for enriching our understanding of the historical record. But sometimes we need to get back to the basics: the "five w's and one h" of sound studies, so to speak. In what follows I'd like to run this simple exercise with radio in the Mandate-era Levant, in order to lay out the basic data of radio broadcasting in this period, and begin to reflect on how it might aid scholars in better understanding other aspects of life in this period. I will do this by first addressing some of these basic what-who-when-where-why and how questions, and then by examining one day's programming from the Palestine Broadcasting Service in 1937: the day immediately following the release of the Peel Commission Report. What can we learn from examining this day's programming?

The 1930s and 1940s were key decades for radio broadcasting around the world, as states consolidated control of the airwaves by establishing government-operated, medium-wave stations in place of the individual and often idiosyncratic broadcasts by amateurs characterizing the 1920s. By the 1930s, European states in particular believed strongly in the power of radio broadcasts to influence listeners—both when crafting programming themselves and when speculating about the power of foreign government broadcasting. At the same time, the technical challenges of medium-wave broadcasting, with signals carried over sizable distances, meant that these national stations often interfered with one another. The International Broadcasting Union, founded in 1925 in Geneva to manage interference issues among member states, hosted the Lucerne Conference of 1933, which allocated wavelengths to each European country. Because interference continued across the Mediterranean, the "European” broadcasting zone stretched to Russia, North Africa, and the Levant. Once European countries established state stations at home, they also began to establish them in their colonial or mandate outposts-including the 
Palestine Broadcasting Service in Jerusalem. At its height, the station likely reached less than half of Mandate Palestine's population on a regular basis; but was considered important enough for the British government to highlight the station in its annual League of Nations report. It was also considered important enough for various dissident and extremist groups to attempt to shut it down or take it over, starting in 1939 and continuing through the end of the Mandate. ${ }^{1}$

Beginning with the what, we might ask: What stations were broadcasting? What kinds of news and entertainment programing did they offer? The biggest station in the region, from the mid 1930s through the Nasser era, was Radio Cairo. Until the end of the Palestine Mandate, the second-most popular, according to a 1943 survey conducted by the American University of Beirut, was the Palestine Broadcasting Service. ${ }^{2}$ Their popularity had in part to do with their budgets: Radio Cairo in particular was reputed to have a larger budget, and hence to attract the best musical artists. However, it also had to do with technical issues: how far each station's signal reached clearly. Radio Damascus in particular could barely be heard outside the city.

Similarly, who was listening? This question is in part about class and discretionary spending: radio sets were affordable luxury goods, and Palestinian companies such as Boutagy's General Stores marketed battery-operated sets to rural customers just as they marketed electricity-powered sets to city dwellers. It also involves age and context: did children listen to the news? Did adults listen to the Children's Hour? How easily could cafe workers listen to the cafe radio set, as compared to patrons? But this question also involves language and politics: the majority of registered radio set owners in Palestine, throughout the life of the Mandate, was Jewish. While the English-language programming may have appealed to a broad audience, the Arabic and Hebrew programming appear to have attracted only Arab and Yishuv listeners, respectively. 
When: When were the stations on air? What was the programming breakdown? How many minutes for news, and at what times? It is illuminating to realize how few hours a radio station might be on air each day: five to six hours was not unusual in the 1930s, and no more than 12 in the 1940s. Radio listening required more than simply turning on a radio set: it required engagement with the programming schedule. When was the news broadcast? In Palestine, the timing of news broadcasts became politicized: Hebrew audiences argued that they should have the later, 9pm news broadcast slot, because Arabic listeners - understood here as rural farmers or fellaheen - tended to go to bed early. When was music broadcast? Of what genre? What about other kinds of programming, whether educational talks, current events talks, or children's hours? How did various stations address religious services and religious holidays? In Palestine, for example, each religious community was allocated a certain number of broadcast hours per year, to be used for holiday broadcasting.

Where: This question divides into two halves: Where were the broadcasts taking place? And where were they being heard? As is still true for television broadcasting, the least expensive and most reliable broadcast programming tended to be in-house. So-called "outside broadcasts" did take place in Palestine starting in the mid-1930s, but they were cumbersome, requiring a cable to connect the microphone recording the broadcast back to the broadcasting studio. The combination of technical and logistical challenges also required additional personnel, making these broadcasts more expensive. For stations that relied on government subsidies rather than advertising revenues and operated at a loss, financial concerns encouraged studio broadcasts.

As for the second half, some listened in family groups, some listened at work, some listened at the neighbor's house. Some listened in mixed settings: mixed ages, mixed sexes, mixed religions. Some listened in public —a village guesthouse, a cafe, a school, a yard —and 
others in private or semi-privacy, at home. Some listened while engaged in other tasks; others appear to have taken radio listening as the primary activity. Thinking through these various listening contexts, including their social implications and impact on how the listener in question experienced news or entertainment, helps animate the daily programming guides.

How: How did people hear the radio broadcasts? The simple answer is: by listening to the radio. We know where people listened. But how did they listen? Memoirs suggest that people listened in groups, and did so attentively; the later practice of turning on a radio for "background" sound was not yet common. But did listeners sit silently, or did they comment on the radio broadcasts as they happened? Did some voices (male, adult?) predominate or express themselves more freely? We know that the British government in particular viewed radio broadcasts through the lens of what scholars term "injection theory,” the idea that people listening to radio take the broadcaster's perspective in as if injected directly into their brains. But we also know from memoirs that people listened critically and even skeptically, particularly with respect to European or Mandatory reports of local and Arab-world news.

Why: Why did governments allocate money and resources to establish and support radio stations? Why did the various people who worked for the stations-as engineers, musicians, newscasters, guest speakers, etc.—choose to do so? Why did the British Mandate government hire the staffers it did—especially those who, like Ibrahim Tuqan, were seen as dissidents? Why did listeners choose to tune in to particular programs? Why did people choose to spend their often limited funds on radio sets? While obtaining definitive answers to these questions is almost impossible, considering them improves our historical analysis.

So what can we learn from looking at the radio progrmming on an important day in the history of Mandate Palestine? Here I use the Palestine Post's version of the PBS broadcasting 
schedule, because it included the full schedule from start up to shut down. (The Arabic and Hebrew presses often printed only the programming for the English section and their respective language.)

\section{Wireless Programmes}

\section{Tonight's Features}

Lord Peel's speech in London will be re-broadcast by the P.B.S. at 10.20pm Arabic and Hebrew translations will be transmitted at 11.05pm and 11.20pm, respectively.

5.30 pm - Time Signal, Weather Forecast and Announcements; Arabic Children’s Hour by 'Aida

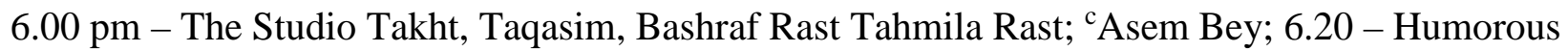
Dialogues by ${ }^{\mathrm{c} A b d}$ el Karim and Yusuf Batruni; 6.35 - News Talk (A[rabic]); 6.45 - LittleKnown Compositions by Bizet. The Studio Ensemble - Leader: Philip Scharf, with Margarethe Czapsky (Mezzo-Soprano) Pictures from the Rhine, Songs, Selections from "The Fair Maid of Perth”.

7.15pm - Arabic Musical Interlude (R[ecorded]); 7.25 - 'Abd el Karim Quartet. Taqasim, Sama’i

Farah Faza. Rumba 'Ajam, Abd el Karim; 7.40 - Humorous Talk by Hilmi Abu Sha’ban (A); 7.55 - Hebrew Lesson by Dr. Itzhaq Epstein.

8.10pm - The Trio of the Studio Ensemble (Scharf - Stubgen - Sacks) Trio in E Minor, Op. 33 Goldmark; 8.40 - "You Have Been Warned" The second of a monthly series of talks by M.S.

O’Rorke, Traffic Superintendent, CID (translated into Hebrew); 8.50 - "Topical Talk” (H[ebrew]); 8.55 - Musical Interlude (R)

9.00pm - Time Signal, Weather Forecast and News in English, Arabic, and Hebrew; 9.30 "Between the Headlines” Dramatised News written by Julian Meltzer and produced by Stephen 
Fry (E[nglish]); 9.45 - Song Recital by Eddie Jamal (Tenor) The Rose Eternal, David Derwood. The Night Wind, Ernst R. Ball. Sing me to Sleep, Edwin Green; 9.55 - Musical Interlude (R). 10.00 pm - Hanna Roumi with the Studio Takht, Taqasim ' Oud. Introduction, Taqasim Violin, Taqasim Kanoun, Layali, Monologue; 10.20 - Lord Peel’s Speech (Rebroadcast from BBC Empire Prog. Trans. IX); 10.35 Orchestral Concert (R); 10.50 - Arabic Music (R). 11.05 pm (Approx.) Lord Peel’s Speech (translated into Arabic); 11.20 (Approx.) Lord Peel’s Speech (translated into Hebrew); 11.35 - (Approx.) - Close Down. ${ }^{3}$

The first point to note is how little on-air time the station had: five to six hours per day. This day included an additional hour of broadcasting; two days prior, the station had shut down around 10:30 pm. ${ }^{4}$ Radio broadcasting was an important innovation, but neither the broadcasters nor, we assume, the listeners expected it to comprise even one-third of the day. (By the 1940s, the station operated three broadcasting sessions: morning, afternoon, and evening.) The second is how little time was allocated to news--a conscious limitation in what the British considered such a volatile territory. The station opened each evening with a weather forecast, but no news; the news was limited to three short broadcasts, in Arabic, English, and Hebrew, at 9 p.m., with two short news analysis talks in Arabic and Hebrew. In other words, only 10 percent of this day's broadcasting time was spent on "hard” news, not counting Lord Peel's speech. Government officials feared the power of radio news far more than they feared that published in the newspapers; the Mandate government exercised tighter control over broadcast news than it did over printed newspapers. The special broadcasting of Lord Peel's speech must be understood as taking place against a backdrop of limited, highly censored radio news, which, we might speculate, only increased its impact on listeners. 
The third point is how much time was devoted to live music: 130 minutes, or over 40 percent of the regular daily broadcasting time. By contrast, the station played 45 minutes of recorded music, approximately 30 minutes of which was used to fill the time between the station's regular shut-down time and the start of Lord Peel's speech. The disparity between the two numbers suggests both the relative cost-effectiveness of in-house musicians and contemporary expectations that a radio station should play live music. Similarly, the focus on classical and "light classical” music reflect British influence: like the BBC, the PBS preferred classical to commercially popular music.

Fourth, the talks broadcast on this day provide a revealing snapshot of Mandate social realities and station officials' view of the role of the PBS. Hebrew lessons were broadcast regularly as a means of reaching Yishuv immigrants—a reminder that the process of making Hebrew a national language took time and effort. (English lessons were also a regular feature.) Arabic listeners had twenty-five minutes of humorous talks and “dialogues.” Hebrew listeners heard what seemed to be a fairly stern talk on driving violations. The Children's Hour was an almost-daily feature, alternating between English, Hebrew, and Arabic. The overall picture that emerges with these talks is an emphasis on education and moral uplift: the talks worked to create two modern populations, accustomed to traffic rules and sanguine in their humor, with paternal care for the well being of their children.

What we do not get from this programming guide, of course, is the audience side. Who tuned in for this special broadcast? How many listened, and in what social contexts? What did listeners say to one another during and after the broadcasts? Did they suck in their breath, shout, clasp hands, go out into the neighborhood streets afterward? Did families encourage children to listen? How did those who listened to the speech process the report differently from those who 
merely read a transcript in the next day’s newspaper? For those who listened in translation, what was the impact of the translator's speed, clarity, timbre, and other qualities? For answers to these questions — which may never be fully answered — we can turn to memoirs, oral histories, and newspaper commentaries.

What we do get from the programming guide is a window into how one of the most important Mandate-era reports was introduced to the peoples of Palestine: late at night, in serial translation, and directly after a set of Arabic music recordings. Broadcasts such as these distinguished news of the late 1930s and beyond from that of earlier eras, because major news events were now often accompanied by special broadcasts, often including the voices of the main figures involved. When we assess the historical impact of reports, treaties, and policies, we should also consider how changing modes of transmission—-from print to broadcast media— impacted their reception.

\footnotetext{
${ }^{1}$ The first attack came in the form of three bombs placed throughout the station in August 1939; two station employees — a Jewish immigrant from South Africa and an Arab Christian—were killed.

2 Stuart C. Dodd, A Pioneer Radio Poll in Lebanon, Syria, and Palestine (Jerusalem: Government Printer, 1943). The other Arabic-language station broadcasting from Palestine, the Near East Broadcasting Service, was believed by British officials to have become more popular than the PBS in the 1940s, due to its Arab nationalist stance, although the station was in fact funded by the British Foreign Office.

3 “Wireless Programmes”, Palestine Post, July 8, 1937, p. 6.

4 “Wireless Programmes”, Palestine Post, July 5, 1937, p. 6.
} 